Planning and Civil Engineering; Economics and Economic History; Education and Psychology; Geography, Agriculture and Natural Resources; History, Political Science and Islamic Studies; Law; Social Anthropology, Sociology and Linguistics; Veterinary Medicine, Social Medicine and Microbiology. At a final plenary session the groups reported briefly on their discussions and the conference as a whole agreed on a number of conclusions. These stressed particularly, among other points, the importance of improving channels of communication (and outlined several ideas on how this improvement might be attempted); the need for rethinking the problems of financing secondments and joint research projects; and the desirability of giving greater attention to the placing of schemes where they fit best into existing activities and of allocating African research students in academic institutions where their interests and talents can be most effectively developed.

A full report of the proceedings of the conference and its conclusions and recommendations will be produced as early as possible.

\title{
African Studies Association: Eighth Annual Meeting
}

THE eighth annual meeting of the African Studies Association was held in Philadelphia from 27 to 30 October 1965 . In addition to plenary sessions devoted to the business of the Association, a series of simultaneous panels was held over two days, at which papers were read and discussed on the following topics: Traditional culture and modern elites-North Africa's vision of Black Africa; the contribution of tradition to the understanding of contemporary political change in West Africa; economic development and social change; national integration in East Africa; news-gathering in and about Africa; changing social patterns; archaeology; education-U.S. universities' aid to African education; modern African history; American policy towards Africa; changing role of women in Africa; problems in the study of att in African society; changing social and political patterns in East Africa; law in society; movements of political and social change in Central Africa; African nationalism; historical perspectives on Southern Africa; aspects of African regionalism; personality; opportunities for science research in Nigeria; the literary conscience of Africa; geography of Africa; linguistics; slavery; Africa and other developing areas; South Africa, the Transkei, and the High Commission Territories; and political perspectives in West Africa.

Professor Joseph $\mathrm{H}$. Greenberg delivered a Presidential address on the place of linguistics in African studies. The first Herskovits Award to be made by the Association was presented to Dr. Ruth Schachter Morgenthau in recognition of her study of Political Parties in FrenchSpeaking West Africa. Professor Rupert Emerson, Professor of Government at Harvard University, was elected President of the Association for 1965-6.

Further information concerning the Association and its activities may be obtained from the Executive Secretary, Professor L. Gray Cowan, 4I I Uris Hall, Columbia University, New York, N.Y. 10027.

\section{International African Seminar on Concepts and Procedures in African Law}

THE eighth in the series of seminars arranged by the International African Institute, with the aid of grants from the Ford Foundation, is being held from 3 to I $_{3}$ January 1966 at Haile Sellassie I University, Addis Ababa, by courtesy of the President. The subject is ' Concepts and Procedures in African Law' and the chairman is Professor Max Gluckman of the University of Manchester. Local arrangements have been made by Professor Richard Pankhurst, Director of the Institute of Ethiopian Studies in Addis Ababa. Papers will be read and discussed on the following themes: judicial methods and problems of evidence and proof; structural position of judicial authorities; law of persons : political and tribal status-familial 